\title{
A NOVEL STABILITY-INDICATING REVERSE PHASE LIQUID CHROMATOGRAPHIC METHOD FOR THE SIMULTANEOUS ESTIMATION OF METFORMIN AND TENELIGLIPTIN IN PURE AND PHARMACEUTICAL FORMULATIONS
}

\section{A. SWETHA ${ }^{*}$, B. RAMYA KUBER ${ }^{2}$}

1Department of Pharmacy, Institute of Pharmaceutical Technology, Sri Padmavathi Mahila Visvavidyalayam, Tirupathi, Andhra Pradesh, India, ${ }^{2}$ Department of Pharmacy, Institute of Pharmaceutical Technology, Sri Padmavathi Mahila Visvavidyalayam, Tirupati, Andhra Pradesh, India

Email: swetha.addanki06@gmail.com

Received: 06 Jul 2017, Revised and Accepted: 02 Nov 2017

\section{ABSTRACT}

Objective: The present method was proposed to develop a simple, sensitive, rapid, accurate and stability-indicating reverse phase-high performance liquid chromatographic (RP-HPLC) method for the simultaneous estimation of metformin and teneligliptin in pure and pharmaceutical formulations.

Methods: The chromatographic separation was done on Discovery [250 mm X $4.6 \mathrm{~mm}: 5 \mu \mathrm{m}$ is particle size] using a mobile phase composed of $0.1 \%$ orthophosphoric acid buffer: acetonitrile [65:35, v/v], the flow rate is $1 \mathrm{ml} / \mathrm{min}$ and the detection was carried out with a photodiode array (PDA) at $260 \mathrm{~nm}$

Results: The retention time of metformin and teneligliptin were found to be 2.517 min and 3.687 min, respectively. Stability indicating studies were conducted under the guidelines of an international conference on harmonization [ICH] Q1A R2 and the developed method was validated as per the guidelines of ICH Q2 R1. The linearity was found in the range of concentration of $125-750 \mu \mathrm{g} / \mathrm{ml}$ and $5-30 \mu \mathrm{g} / \mathrm{ml}$ for metformin and teneligliptin. The lower limit of detection (LOD) and lower limit of quantification (LOQ) was found to be $0.02 \mu \mathrm{g} / \mathrm{ml}$ and $0.07 \mu \mathrm{g} / \mathrm{ml}$ for metformin and $0.19 \mu \mathrm{g} / \mathrm{ml}$ and $0.56 \mu \mathrm{g} / \mathrm{ml}$ for teneligliptin, respectively.

Conclusion: A novel stability-indicating reverse phase liquid chromatographic method developed for the simultaneous estimation of metformin and teneligliptin. The proposed method was adopted for the routine estimation of metformin and teneligliptin in bulk and pharmaceutical dosage forms.

Keywords: Method validation, Estimation, Stability indicating, RP-HPLC, Metformin, Teneligliptin

(C) 2018 The Authors. Published by Innovare Academic Sciences Pvt Ltd. This is an open access article under the CC BY license (http://creativecommons.org/licenses/by/4.0/) DOI: http://dx.doi.org/10.22159/ijap.2018v10i5.29568

\section{INTRODUCTION}

Metformin (fig. 1) category is biguanide and chemically called as $\mathrm{N}$, $\mathrm{N}$-dimethyl imidodicarbonimidic diamide hydrochloride. It is used for the treatment of type 2 diabetes, and limited use to prevent the cardiovascular disease and cancer complications of diabetes [1].

Teneligliptin (fig. 2) is potent, competitive and long-acting DPP-1V inhibitor and chemically called as $\{(2 S, 4 S)-4$-[4-(3-methyl-1-phenyl1H-pyrazol-5-yl)-1-piperazinyl]-2-pyrrolidinyl $\}$ (1,3-thiazolidin-3-yl) methanone. It is used for the treatment of type-2 diabetic mellitus [2].

Literature survey revealed that very few analytical method had been reported for the estimation of metformin and teneligliptin by using ultraviolet spectroscopy [3-6], HPLC [7-10], ultra performance liquid chromatography (UPLC) [11-12], and liquid chromatography-mass spectroscopy (LC-MS) [13-14] by individually or simultaneously with other drugs. From the literature survey, it confirms that there is no method has been reported for the stability indicating a simultaneous estimation of metformin and teneligliptin in pure and pharmaceutical dosage form by using RP-HPLC.

The present method has so many advantages like simple standard preparation process, a large range of concentration with high sensitivity, low-cost solvent are used in mobile phase preparation and all parameters must be validated as per ICH guidelines [15-16]. Hence, the developed method was used for the simultaneous determination of metformin and teneligliptin in pure and pharmaceutical dosage forms.

\section{MATERIALS AND METHODS}

\section{Instruments}

The system composed Waters HPLC 2695 equipped with quaternary pumps with PDA detector. The chromatographic separation was done on Discovery [250 mm X $4.6 \mathrm{~mm}, 5 \mu \mathrm{m}$ particle size] column.
Empower 2 software was used for the data acquisition and integration purpose.<smiles>CN(C)C(=N)N=C(N)N</smiles><smiles>[CH]=C</smiles>

Fig. 1: structure of metformin [17]

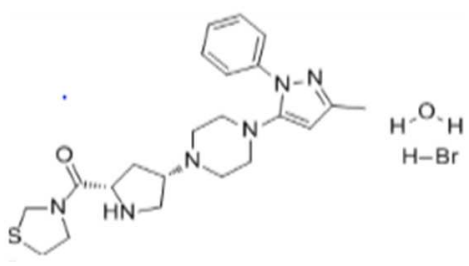

Fig. 2: Structure of teneligliptin [17]

\section{Chemical solutions and reagents}

Metformin and Teneligliptin obtained from Spectrum Research Private limited, [Hyderabad, India]. Orthophosphoric acid purchased from Qualigens fine chemicals limited [Mumbai, India] and acetonitrile [HPLC grade] purchased from Merck chemicals private limited [Mumbai, India]. 


\section{Preparation of standard and working standard solutions}

The powder of $50 \mathrm{mg}$ of metformin and $2 \mathrm{mg}$ of teneligliptin were weighed and transferred into a $100 \mathrm{ml}$ of calibrated volumetric flasks, $70 \mathrm{ml}$ of diluent was added and sonicated for $25 \mathrm{~min}$ and makeup to the final volume with diluents. $1 \mathrm{ml}$ was pipetted out from above stock solution and transferred into $10 \mathrm{ml}$ volumetric flask and made up to $10 \mathrm{ml}$ with diluent.

\section{Preparation of mobile phase buffer}

The buffer solution was prepared by dissolving $1 \mathrm{ml}$ orthophosphoric acid in $1000 \mathrm{ml}$ of water.

\section{Mobile phase composition}

Method development for the simultaneous estimation of metformin and teneligliptin was begun with a different combination of solvents with different ratios like [35:65, 45:55, and 50:50]. Although, finally a combination of $0.1 \%$ orthophosphoric acid buffer: acetonitrile [65:35, $\mathrm{v} / \mathrm{v}]$ has appeared good resolution for metformin and teneligliptin.

\section{Sample preparation}

20 tablets were weighed and calculate the average weight of each tablet then the weight equivalent to 1 tablet was transferred into a $100 \mathrm{ml}$ volumetric flask, $70 \mathrm{ml}$ of diluent added and sonicated for 25 min, further the volume made up with diluent and filtered. From the filtered solution $1 \mathrm{ml}$ was pipetted out into a $10 \mathrm{ml}$ volumetric flask and made up to $10 \mathrm{ml}$ with diluent.

\section{Chromatographic conditions}

The method development for separation of metformin and teneligliptin by using different solvents, finally the separation was achieved with a mobile phase $0.1 \%$ orthophosphoric acid buffer: acetonitrile [65:35, $\mathrm{v} / \mathrm{v}]$, pumped at a flow rate is $1 \mathrm{ml} / \mathrm{min}$. The eluent detection was carried out at $260 \mathrm{~nm}$, by observing of PDA detector. The mobile phase was vacuum filtered through a $0.45 \mu \mathrm{m}$ membrane filter.

\section{Method validation}

The developed method was validated according to 2005 ICH guidelines for validation of analytical procedures. Validation parameters according to the guideline of ICH Q2R1 include system suitability, linearity, precision, LOD, LOQ and accuracy, robustness under the guideline.

\section{System suitability}

Verifying the system suitability parameters like theoretical plate count, tailing factor, percentage relative standard deviation of the peak and retention time, resolution, system suitability tests were carried out to ensure optimized chromatographic conditions are suitable for analysis of metformin and teneligliptin. Mixed standard solutions containing metformin $(500 \mu \mathrm{g} / \mathrm{ml})$ and teneligliptin $(20 \mu \mathrm{g} / \mathrm{ml})$ were prepared. Six replicate injections of the above standard solutions were injected into the column. System suitability parameters of typical chromatograms were analyzed using the proposed HPLC method.

\section{Linearity, range and calibration curve}

The range of linearity was evaluated between $125-750 \mu \mathrm{g} / \mathrm{ml}$ for metformin and $5-30 \mu \mathrm{g} / \mathrm{ml}$ and for teneligliptin at an injection volume of $10 \mu \mathrm{l}$. The calibration curve was a plot between concentration against corresponding peak area and linearity was estimated by the least square method.

\section{Precision}

The precision of the developed method was carried out for same concentration level in terms of repeatability and intermediate precision. Six determinations were established, both intra-day and inter-day precision were conveyed in terms of percent relative standard deviation [\% RSD].

\section{LOD and LOQ}

Determination value of the limit of detection and quantification by using the following formulas:

\section{Limit of detection $=3.3 \alpha / \mathrm{S}$}

Limit of quantitation $=10 \alpha / \mathrm{S}$

Where $\alpha$ is the standard deviation of the $y$-intercept and S is the slope from linearity plot

\section{Accuracy}

The accuracy was estimated by using the standard addition method at $50 \%, 100 \%$, and $150 \%$ levels. The percentage recovery and percentage relative standard deviations [\%RSD] were taken into consideration for examine the accuracy.

\section{Specificity}

Specificity was established by comparing 3D plots of pure drug and drug product with blank and placebo, and by peak purity test, which shown that analyte chromatographic peak is not determinable to more than two components and no impurities are available by peak purity index. The data was given in fig. 9 and 10.

\section{Robustness}

Robustness was estimated by making slight and deliberate changes in chromatographic conditions like flow rate, mobile phase. The data was summarized in table 8 and 9.

\section{Stability indicating studies \\ Acid hydrolysis}

$1 \mathrm{ml}$ stock solution of metformin and teneligliptin, $1 \mathrm{ml}$ of $2 \mathrm{~N}$ hydrochloric acid was added and refluxed for $30 \mathrm{~min}$ at $60^{\circ} \mathrm{C}$. The solution was diluted to obtain $500 \mu \mathrm{g} / \mathrm{ml}$ for metformin and 20 $\mu \mathrm{g} / \mathrm{ml}$ for teneligliptin. $10 \mu \mathrm{l}$ solutions were injected into the system and the chromatograms were recorded to assess the stability of the sample.

\section{Base hydrolysis}

$1 \mathrm{ml}$ stock solution of metformin and teneligliptin, $1 \mathrm{ml}$ of $2 \mathrm{~N}$ sodium hydroxide was added and refluxed for $30 \mathrm{~min}$ at $60^{\circ} \mathrm{C}$. The solution was diluted to obtain $500 \mu \mathrm{g} / \mathrm{ml}$ for metformin and 20 $\mu \mathrm{g} / \mathrm{ml}$ for teneligliptin. $10 \mu \mathrm{l}$ solutions were injected into the system and the chromatograms were recorded to assess the stability of the sample.

\section{Peroxide hydrolysis}

$1 \mathrm{ml}$ stock solution of metformin and teneligliptin, $1 \mathrm{ml}$ of $20 \%$ hydrogen peroxide was added and refluxed for $30 \mathrm{~min}$ at $60^{\circ} \mathrm{C}$. The solution was diluted to obtain $500 \mu \mathrm{g} / \mathrm{ml}$ for metformin and 20 $\mu \mathrm{g} / \mathrm{ml}$ for teneligliptin. $10 \mu \mathrm{l}$ solutions were injected into the system and the chromatograms were recorded to assess the stability of the sample.

\section{Thermal hydrolysis}

$1 \mathrm{ml}$ stock solution of metformin and teneligliptin, placed in oven at $105{ }^{\circ} \mathrm{C}$ for $6 \mathrm{~h}$. The solution was diluted to obtain $500 \mu \mathrm{g} / \mathrm{ml}$ for metformin and $20 \mu \mathrm{g} / \mathrm{ml}$ for teneligliptin. $10 \mu \mathrm{l}$ solutions were injected into the system and the chromatograms were recorded to assess the stability of the sample.

\section{Photo hydrolysis}

Exposing the $5000 \mu \mathrm{g} / \mathrm{ml}$ for metformin and $200 \mu \mathrm{g} / \mathrm{ml}$ for teneligliptin solution to UV Light by keeping the beaker in UV chamber for 7 days or 200 Watt-hours $/ \mathrm{m}^{2}$ in photostability chamber. The resultant solution was diluted to obtain $500 \mu \mathrm{g} / \mathrm{ml}$ for metformin and $20 \mu \mathrm{g} / \mathrm{ml}$ for teneligliptin solutions. $10 \mu \mathrm{l}$ were injected into the system, and the chromatograms were recorded to assess the stability of the sample.

\section{Neutral hydrolysis}

Refluxing the drug solutions in water for $6 \mathrm{~h}$. at a temperature at $60^{\circ} \mathrm{C}$. The solution was diluted to obtain $500 \mu \mathrm{g} / \mathrm{ml}$ for metformin and 20 $\mu \mathrm{g} / \mathrm{ml}$ for teneligliptin. $10 \mu \mathrm{l}$ solutions were injected into the system and the chromatograms were recorded to assess the stability of the sample. 


\section{RESULTS}

\section{Optimization of chromatographic conditions}

The analytical conditions were selected, keeping in mind the chemical nature of metformin and teneligliptin. The development trails were taken using different conditions. The column selection has been done on the basis of back pressure, peak shape and theoretical plates. After evaluating all these factors, the chromatographic separation was carried out on Discovery column
[250 mm X $4.6 \mathrm{~mm} ; 5 \mu \mathrm{m}$ is particle size] using a mobile phase consisting $0.1 \%$ orthophosphoric acid buffer: acetonitrile [65:35 $\mathrm{v} / \mathrm{v}$, the flow rate $1 \mathrm{ml} / \mathrm{min}$ and the injection volume were $10 \mu \mathrm{l}$, the detection was carried out with PDA detector at $260 \mathrm{~nm}$. The peak retention time of metformin and teneligliptin were found to be 2.517 min and 3.687 min respectively. Hence this method was finalized as an optimized method for the simultaneous estimation of metformin and teneligliptin. The optimized chromatographic condition was shown in table 1 and the typical HPLC chromatogram of blank, standard and placebo, the sample were shown in fig. 3, 4 and 5, 6 .

Table 1: Optimized chromatographic condition for the estimation of metformin and teneligliptin

\begin{tabular}{ll}
\hline Parameter & Condition \\
\hline Mobile phase & $0.1 \%$ Ortho phosphoric acid buffer: acetonitrile $[65: 35 \mathrm{v} / \mathrm{v}]$ \\
Diluent & Water: acetonitrile \\
Column & Discovery $(250 \mathrm{~mm} \times 4.6 \mathrm{~mm}, 5 \mu \mathrm{m}$ is particle size $)$ \\
Detector & PDA \\
Column temperature & $30^{\circ} \mathrm{C}$ \\
Detection wavelength & $260 \mathrm{~nm}$ \\
Injection volume & $10 \mu \mathrm{l}$ \\
Flow rate & $1 \mathrm{ml} / \mathrm{min}$ \\
Run time & $6 \mathrm{~min}$ \\
\hline
\end{tabular}

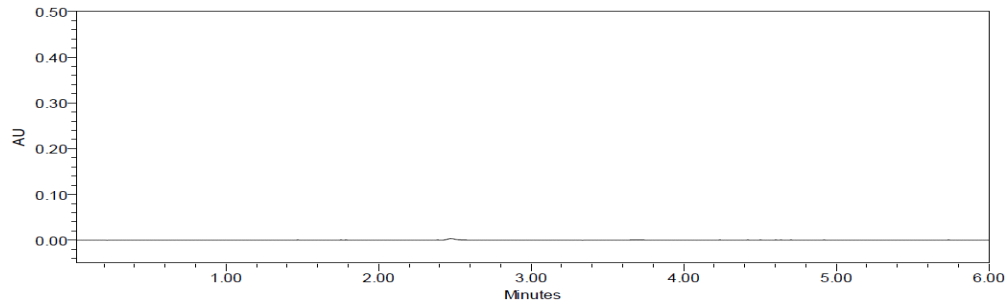

Fig. 3: Typical HPLC chromatogram of blank

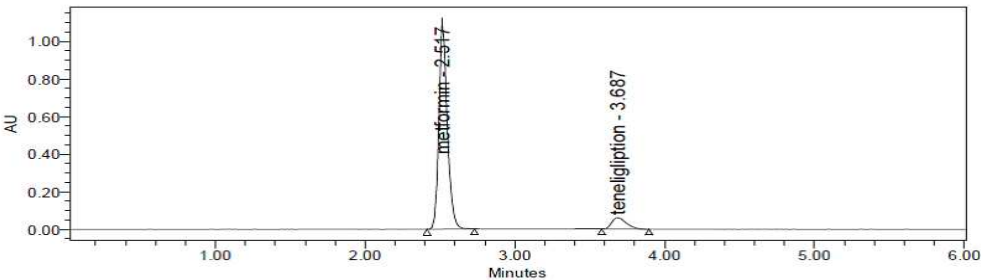

Fig. 4: Typical HPLC chromatogram of standard

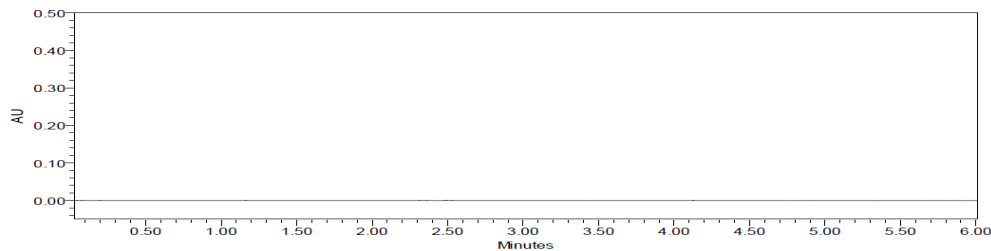

Fig. 5: Typical chromatogram of placebo

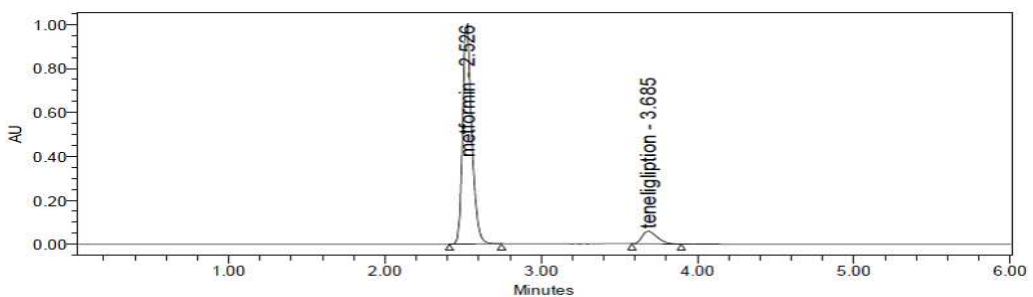

Fig. 6: Typical HPLC chromatogram of a sample 


\section{System suitability}

The developed method has produced a theoretical plate above 2000 for metformin and teneligliptin with tailing factor less than 2 .
Similarly, the percent relative standard deviation [\% RSD] of metformin and teneligliptin were less than 2 , which ensure the suitability of the developed method. The results of the system suitability study were summarized in table 2 .

Table 2: System suitability of the developed method

\begin{tabular}{llll}
\hline Parameters & Metformin & Teneligliptin & Acceptance criteria \\
\hline Retention time(min) & 2.517 & 3.687 & $\ldots \ldots$. \\
Theoretical plates & 9788 & 6734 & $>2000$ \\
Tailing factor & 1.22 & 1.40 & $<2$ \\
Asymmetry factor & 1.68 & 1.75 & $>1<10$ \\
Resolution & 8.0 & 8.0 & $>2$ \\
\hline
\end{tabular}

\section{Linearity}

For linearity of six point's calibration curve were obtained in concentration ranges from $125-750 \mu \mathrm{g} / \mathrm{ml}$ for metformin and 5-30 $\mu \mathrm{g} / \mathrm{ml}$ for teneligliptin. The response of the drug was found to be

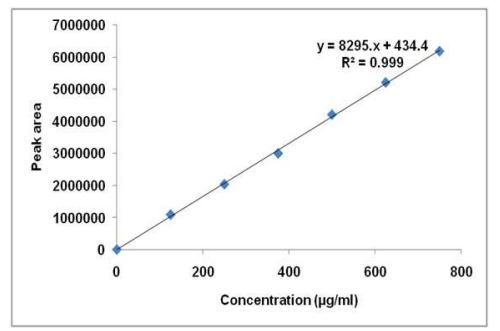

[A] linear in the selected concentration range. The correlation coefficient for metformin and teneligliptin were 0.9993 and 0.9991 respectively. The results of the linearity of metformin and teneligliptin were summarized in table 3 and 4 and the data was shown in fig. 7

Fig. 7: Standard calibration curve of [A] metformin [B] teneligliptin

Table 3: Linearity and range of Metformin $(n=3)$

\begin{tabular}{|c|c|c|}
\hline S. No. & Concentration $(\mu \mathrm{g} / \mathrm{ml})$ & Peak area (mean \pm SD) \\
\hline 1 & 125 & $1092284 \pm 1850.1$ \\
\hline 2 & 250 & $2040782 \pm 14336.2$ \\
\hline 3 & 375 & $3006306 \pm 7370.4$ \\
\hline 4 & 500 & $4217649 \pm 28145.6$ \\
\hline 5 & 625 & $5222174 \pm 24778.4$ \\
\hline 6 & 750 & $6198935 \pm 17844.1$ \\
\hline Slope & & 8295.3 \\
\hline Y-intercept & & 434.4 \\
\hline Correlation coefficient & & 0.9993 \\
\hline
\end{tabular}

$\mathrm{n}$ is number of determination, SD is standard deviation

Table 4: Linearity and range of Teneligliptin $(n=3)$

\begin{tabular}{lll}
\hline S. No. & Concentration $(\boldsymbol{\mu g} / \mathbf{m l})$ & Peak area (mean $\mathbf{S D})$ \\
\hline 1 & 5 & $106601 \pm 606.5$ \\
2 & 10 & $205080 \pm 880.5$ \\
3 & 15 & $294146 \pm 5729.8$ \\
4 & 20 & $380439 \pm 2798.5$ \\
5 & 25 & $473114 \pm 5898.1$ \\
6 & 30 & $569050 \pm 7931.1$ \\
Slope & & 18682 \\
Y-intercept & & 9539.8 \\
Correlation coefficient & & 0.9991 \\
\hline
\end{tabular}

$\mathrm{n}$ is number of determination, SD is standard deviation

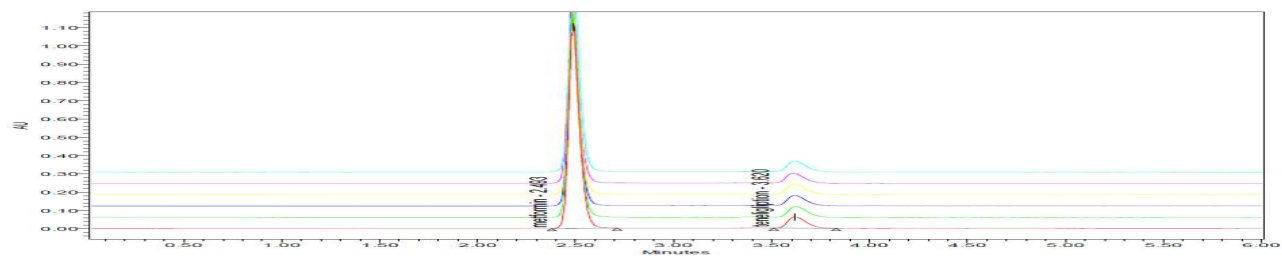

Fig. 8: Overlay of precision chromatograms 
Table 5: Intra-day and inter-day precision of the developed method for metformin $(n=6)$

\begin{tabular}{lllll}
\hline Drug & $\begin{array}{l}\text { Concentration } \\
(\boldsymbol{\mu g} / \mathbf{m l})\end{array}$ & Intra-day precision & \multicolumn{2}{c}{ Inter-day precision } \\
\cline { 2 - 5 } & 500 & mean \pm SD & \%RSD & mean \pm SD \\
\hline Metformin & 500 & $4248866 \pm 32475$ & 0.8 & $4203360 \pm 12451.8$ \\
\hline
\end{tabular}

$\mathrm{n}$ is number of determination, SD is standard deviation, RSD is relative standard deviation

Table 6: Intra-day and inter-day precision of the developed method for teneligliptin (n=6)

\begin{tabular}{lllll}
\hline Drug & $\begin{array}{l}\text { Concentration } \\
(\boldsymbol{\mu} / \mathbf{m l})\end{array}$ & Intra-day precision & \multicolumn{1}{c}{ Inter-day precision } \\
\cline { 2 - 5 } & 20 & mean \pm SD & \%RSD & mean \pm SD \\
\hline Teneligliptin & 20 \%RSD & 0.7 & $334998 \pm 1130.5$ \\
\hline
\end{tabular}

$\mathrm{n}$ is number of determination, SD is standard deviation, RSD is relative standard deviation

\section{Precision}

The developed method has shown percent relative standard deviation [\% RSD] less than 2 for both intra-day and inter-day precision study, which ensures precision of the developed method. The results of the precision study were summarized in table 5 and 6, and the data was shown in fig. 8.

Lower limit of detection (LOD) and lower limit of quantification (LOQ)

LOD and LOQ were estimated from the standard deviation of the $y$ intercepts and slope of the calibration curve of metformin and teneligliptin. The LOD and LOQ were found to be 0.02 and 0.07 $\mu \mathrm{g} / \mathrm{ml}$ for metformin and 0.19 and $0.56 \mu \mathrm{g} / \mathrm{ml}$ for teneligliptin. This showed that the developed method can detect and quantify at lower concentration was highly sensitive whereas other methods is less sensitive.

\section{Accuracy}

The percentage recovery of the spiked sample was within $99 \pm 2 \%$ which ensures the accuracy of the developed method. The results of recovery studies were summarized in table 7 and 8 .

\section{Specificity}

Specificity was established by spiking diluent solution of tablet formulation excipients (placebo). The resultant chromatogram shown that no peaks at $\mathrm{R}_{\mathrm{t}}$ of metformin 2.517 and teneligliptin 3.687 .

Table 7: Accuracy of the developed method for metformin $(n=3)$

\begin{tabular}{|c|c|c|c|c|c|}
\hline Drug name & $\begin{array}{l}\text { Level of addition } \\
\text { (\%) }\end{array}$ & $\begin{array}{l}\text { Amount added } \\
\text { (mg) }\end{array}$ & $\begin{array}{l}\text { Drug found } \\
(\mathrm{mg} / \mathrm{ml}) \text { mean } \pm S D\end{array}$ & $\%$ Recovery mean \pm SD & $\begin{array}{l}\text { Average \% recovery } \\
\text { mean } \pm S D\end{array}$ \\
\hline \multirow{3}{*}{ Metformin } & 50 & 250 & $247.3 \pm 2.23$ & $98.5 \pm 0.2$ & \multirow{3}{*}{$98.8 \pm 0.68$} \\
\hline & 100 & 500 & $493.1 \pm 3.61$ & $98.62 \pm 0.7$ & \\
\hline & 150 & 750 & $744.1 \pm 6.96$ & $99.2 \pm 0.93$ & \\
\hline
\end{tabular}

$\mathrm{n}$ is number of determination, SD is standard deviation

Table 8: Accuracy of the developed method for teneligliptin $(n=3)$

\begin{tabular}{lllll}
\hline Drug name & $\begin{array}{l}\text { Level of addition } \\
\text { (\%) }\end{array}$ & $\begin{array}{l}\text { Amount added } \\
\text { (mg) }\end{array}$ & $\begin{array}{l}\text { Drug found (mg/ml) } \\
\text { mean } \pm \text { SD }\end{array}$ & $\begin{array}{l}\text { \% Recovery } \\
\text { mean } \pm \text { SD }\end{array}$ \\
\hline \multirow{3}{*}{ Teneligliptin } & 50 & 10 & $9.91 \pm 0.03$ & $\begin{array}{l}\text { Average \% recovery } \\
\text { mean } \pm \text { SD }\end{array}$ \\
& 100 & 20 & $19.9 \pm 0.18$ & $99.11 \pm 0.36$ \\
& 30 & $29.8 \pm 0.4$ & $99.83 \pm 0.92$ \\
& 150 & $99.46 \pm 0.89$ & 9.34 \\
\hline
\end{tabular}

$\mathrm{n}$ is number of determination, SD is standard deviation

Table 9: Robustness of developed method for metformin $(n=6)$

\begin{tabular}{lll}
\hline Parameter & Peak area (mean \pm SD) \\
\hline Flow rate plus $(70: 30 \mathrm{v} / \mathrm{v})$ & $3754398 \pm 13745.3$ & \%RSD \\
Flow rate minus $(60: 40 \mathrm{v} / \mathrm{v})$ & $4601714 \pm 26047.6$ & 0.4 \\
Mobile phase plus $(1.1 \mathrm{ml})$ & $3798055 \pm 14382.3$ & 0.6 \\
Mobile phase minus $(0.9 \mathrm{ml})$ & $3776325 \pm 15684.8$ & 0.4 \\
\hline
\end{tabular}

$\mathrm{n}$ is number of determination, SD is standard deviation, RSD is relative standard deviation

Table 10: Robustness of the developed method for teneligliptin $(n=6)$

\begin{tabular}{lll}
\hline Parameter & Peak area (mean \pm SD) \\
\hline Flow rate plus $(70: 30 \mathrm{v} / \mathrm{v})$ & $325266 \pm 4911.8$ & \%RSD \\
Flow rate minus $(60: 40 \mathrm{v} / \mathrm{v})$ & $366352 \pm 2611.8$ & 1.5 \\
Mobile phase plus $(1.1 \mathrm{ml})$ & $306216 \pm 2145.2$ & 0.7 \\
Mobile phase minus $(0.9 \mathrm{ml})$ & $346556 \pm 4557.2$ & 0.7 \\
\hline
\end{tabular}

$\mathrm{n}$ is number of determination, SD is standard deviation, RSD is relative standard deviation 




[A]

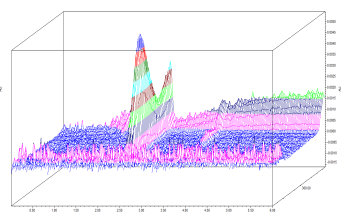

[B]

Fig. 9: 3D plot of $[A]$ Standard [B] Blank

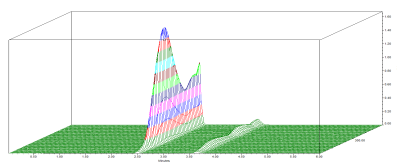

[A]

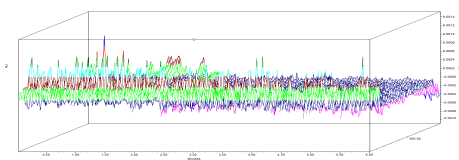

[B]

Fig. 10: 3D plot of $[A]$ Sample $[B]$ Placebo

\section{Assay}

The assay was estimated by injecting prepared concentration of tablet formulation into HPLC. Assay result was calculated by comparing the peak area of tablet formulation with a peak area of standard solution.
$\%$ assay of metformin and teneligliptin was found to be $99.47 \%$ and $100.24 \%$ respectively. $\%$ assay for both drugs was found to be more than $99.4 \%$. Hence the method was successfully applied for estimation of metformin and teneligliptin in bulk and pharmaceutical formulation. The results of assay data were summarized in table 11.

Table 11: Assay data for formulation of metformin and teneligliptin $(n=6)$

\begin{tabular}{llll}
\hline Formulation & Labelled amount $(\mathbf{m g})$ & \% Assay (mean \pm SD) & \% RSD \\
\hline Totaglipt M & Metformin-500 mg & $99.47 \pm 0.76$ & 0.76 \\
& Teneligliptin-20 mg & $100.24 \pm 0.7$ & 0.7 \\
\hline
\end{tabular}

$\mathrm{n}$ is number of determinations, $\mathrm{SD}$ is standard deviation, RSD is relative standard deviation

\section{Stability-indicating studies}

Stability indicating studies were carried under a condition of acid/base/neutral hydrolysis, oxidation, dry heat and photolysis. For each study, samples were prepared. The blank subjected to stress in the same manner for the drug solution, working standard solution of metformin and teneligliptin subjected to stress degradation. Dry heat and photolytic degradation were carried out in a solid state. The concentration of degrading reagent and time of exposure was optimized to degradation within the range of $10 \%$. During optimization of degradation conditions, if the higher percentage of degradation was observed, milder conditions were used for the lesser duration of exposure.

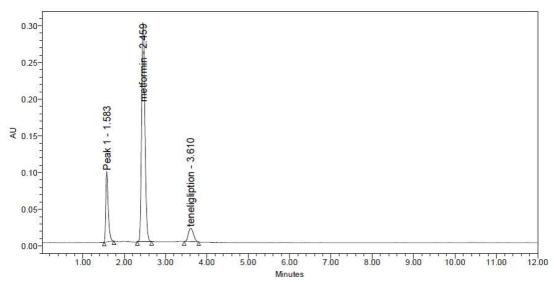

Degradation product peak at $\mathrm{R}_{\mathrm{t}}$ of $\mathbf{1 . 5 8 3}$ Fig. 11: Chromatogram of acid hydrolysis

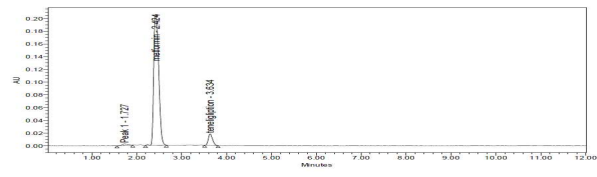

Degradation product peak at $R_{t}$ of 1.727

Fig. 12: Chromatogram of alkali hydrolysis

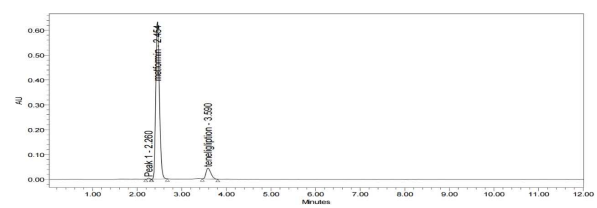

Degradation product peak at $R_{t}$ of 1.260

Fig. 13: Chromatogram of peroxide hydrolysis

Although percent assay reduced under all conditions; the separate peak for degradation product was observed only under acid, alkali and oxidative conditions showing in fig 11, 12 and 13. Summary of stress degradation results is given in table 12 and 13.

Table 12: Stability-indicating data of metformin

\begin{tabular}{|c|c|c|c|c|}
\hline Degradation parameter & Peak area of the sample & $\begin{array}{l}\text { Peak area of } \\
\text { standard }\end{array}$ & \% Recovery & \% Degradation \\
\hline Acid degradation & 4059092 & 4267272 & 95.03 & 4.97 \\
\hline Alkali degradation & 4155479 & 4267272 & 97.28 & 2.72 \\
\hline Oxidative degradation & 4191118 & 4267272 & 98.12 & 1.88 \\
\hline Dry heat degradation & 4248957 & 4267272 & 99.47 & 0.53 \\
\hline Photo stability degradation & 4247378 & 4267272 & 99.43 & 0.57 \\
\hline Neutral degradation & 4236053 & 4267272 & 99.17 & 0.83 \\
\hline
\end{tabular}


Table 13: Stability-indicating data of teneligliptin

\begin{tabular}{|c|c|c|c|c|}
\hline Degradation parameter & Peak area of sample & Peak area of standard & \% Recovery & \% Degradation \\
\hline Acid degradation & 366712 & 385565 & 95.02 & 4.98 \\
\hline Alkali degradation & 375116 & 385565 & 97.19 & 2.81 \\
\hline Oxidative degradation & 379152 & 385565 & 98.24 & 1.76 \\
\hline Dry heat degradation & 382367 & 365565 & 99.07 & 0.93 \\
\hline Photo stability degradation & 383633 & 385565 & 99.40 & 0.60 \\
\hline Neutral degradation & 382781 & 385565 & 99.18 & 0.82 \\
\hline
\end{tabular}

\section{DISCUSSION}

Stability indicating RP-HPLC method is a simple, rapid, precise, accurate method for analyzing each component in the mixture. The previous study had reported that determination of metformin and teneligliptin by three differential spectrophotometric methods [6]. In this RP-HPLC method, we used PDA detector to prove the selectivity of the method. The method was validated according to ICH guidelines on validation of analytical procedures and stability testing of new drug substances and products. In order to develop an RP-HPLC method for estimation of metformin and teneligliptin, different buffer ratios at different flow rates were applied. As $0.1 \%$ orthophosphoric acid buffer: acetonitrile $[65: 35 \mathrm{v} / \mathrm{v}]$ as mobile phase and discovery C18 column stationary phase was selected. Separation of metformin at $2.517 \mathrm{~min}$ and teneligliptin at 3.687 min was detected by PDA detector. The previous study had reported that simultaneous estimation of metformin and teneligliptin with UV detector at different mobile phase and different column, separation of metformin and teneligliptin was detected at 3.317 min and $4.783 \mathrm{~min}$ [10]. In the reported method, separation of metformin and teneligliptin was 1 min longer than this method and no stability indicating studies were reported. In this method, PDA detector able to identify metformin, teneligliptin and degradation products. Method was validated, the result of validation parameters had shown in compliance of ICH guidelines. The range of linearity had good correlation with concentration and peak area. The correlation coefficient for metformin and teneligliptin were 0.9993 and 0.9991 respectively, which indicates that at this concentration range both were highly linear. Present assay, the amount of both the drugs recovered was found to be $98.78 \%$ for metformin and $99.46 \%$ for teneligliptin. Hence, the developed RP-HPLC stability indicating assay method was found to be appropriate for the analysis of drug in their pharmaceutical dosage form. Separation of degradation peak for degradation product was observed under acidic, alkaline hydrolysis and oxidation conditions at $1.583 \mathrm{~min}$, $1.727 \mathrm{~min}, 1.260 \mathrm{~min}$ respectively. Compared to the previous method, this method is stability indicating, selective, sensitive and separation was detected at the shorter run time.

\section{CONCLUSION}

The newly developed RP-HPLC method for simultaneous determination of metformin and teneligliptin in pure and in the pharmaceutical formulation was found to be simple, sensitive, rapid, precise and accurate. The proposed method was completely validated as per ICH guidelines. The method was proved to be superior to previous methods in terms of selectivity, sensitivity, and stability indicating studies. The method validation data are showing satisfactory results for all the method parameters tested. The stability-indicating nature of the proposed method was established by performing forced degradation, which provided degradation behavior of metformin and teneligliptin under various conditions and it was proved that stressed samples do not interfere with degradation products and excipients. Hence the developed RP-HPLC method is stability-indicating and can be used for routine analysis of production samples and also to check the stability of bulk samples of metformin and teneligliptin.

\section{AUTHORS CONTRIBUTIONS}

The first author Swetha addanki had done almost all steps in the present work and the second author B Ramya kuber was a mentor of the study.

\section{CONFLICT OF INTERESTS}

Declared none

\section{REFERENCES}

1. Marc F, Bruno G, Luc B, Michael P, Benoit V. Metformin: from mechanics of action to therapies. Cell Metab 2014;20:953-66.
2. Miyako K. Teneligliptin: a DPP-4 inhibitor for the treatment of type 2 diabetes. Diabetics Metabolic Syndrome Obesity: Targets Therapy 2013;6:187-95.

3. Kaushelendra M, Himesh S, Nayak G, Patel SS, Singhai AK. Method development and validation of metformin hydrochloride in tablet dosage form. E J Chem 2011;8:1309-13.

4. Chirag, Amrita P. Development, and validation of UV spectrophotometric method for simultaneous estimation of metformin hydrochloride and alogliptin benzoate in bulk drugs and combined dosage forms. Pharm Chem 2014;6:303-11.

5. Ravi K, Ramesh B, Garima K, Rubina B. Development and validation of novel spectrophotometric method for simultaneous estimation of pioglitazone and metformin in bulk and fixed dosage form by Area under curve and Dual wavelength mode. Int J Appl Pharm 2016;8:48-53.

6. Ashim KS, Denish NH, Dhanya BS, Aarti SZ, Rajesh AM, Vikas RC. Analytical method development and validation for simultaneous estimation of teneligliptin hydrobromide hydrate and metformin hydrochloride from its pharmaceutical dosage form by three different UV spectrophotometric methods. J Appl Pharm Sci 2016;6:157-65.

7. Murthy TGK, Geethanjali J. Development of a validated RPHPLC method for simultaneous estimation of metformin hydrochloride and rosuvastatin calcium in bulk and in-house formulation. J Chromatogr Sep Tech 2014;5:252-9.

8. Doredla NR, Mannepalli C. Method development and validation of rp-hplc method for simultaneous analysis of three component tablet formulation containing metformin hydrochloride, pioglitazone hydrochloride and glibenclamide. Int J Pharm Tech Res 2012;4:948-56.

9. Geetha SP, Lakshmana RK, Prasad KRS, Suresh BK. Development and validation of stability are indicating a reverse phase highpressure liquid chromatography method for simultaneous estimation of metformin and empagliflozin in bulk and tablet dosage form. Asian J Pharm Clin Res 2016;9:126-35.

10. Deepak P, Sufiyan A, Shastry VM, Tabrej M, Lalit T. Analytical method development and validation for simultaneous estimation of metformin and teneligliptin by RP-HPLC in bulk and dosage form. J Pharm Res 2017;11:676-81.

11. Madana GN, Sridhar C. A validated stability indicating Ultra performance liquid chromatographic method for simultaneous estimation of metformin hydrochloride and empagliflozin in bulk and tablet dosage form. Int J Appl Pharm 2017;9:45-50.

12. Kumar TNVG, Vidyadhara S, Ashok NN, Sai SY, Lakshmi, Rajyalakshmi M. Method development, validation, and stability studies of teneligliptin by rp-hplc and identification of degradation products by UPLC tandem mass spectroscopy. J Anal Sci Tech 2016;7:18-26.

13. James DTB, Kannappan, Sasijith, Suresh K. Simultaneous estimation and method development for L-Carnitine and metformin in human plasma using the liquid chromatography-mass spectrometer. Asian J Pharm Clin Res 2015:8:185-91.

14. Raja HBC, Gowri SD. Development and validation of lc-ms/ms method for quantification of teneligliptin in human plasma and its application to a pharmacokinetic study. World J Pharm Pharm Sci 2016;5:838-50.

15. Guidelines for validation of Analytical Procedures, Q2(R1), ICH; 2005.

16. Guideline on stability testing of new drug substances and products text and methodology, Q1A (R2), ICH; 2003.

17. Patil M, Jani HD, Khoja SS, Pirani NA, Shamim SK. A review on chemistry and pharmacological activity of metformin hydrochloride and teneligliptin hydrobromide in the combined dosage form. Pharma Tutor 2017;5:24-30. 